\title{
Chapter 19 \\ Preparing of Masters of Vocational \\ Education for Conducting \\ Research Activities
}

\author{
Gafurjon Hakimov and Kalybek Dykanaliev
}

\subsection{Introduction}

The science is a real advantage for people. (Wolfgang Goethe)

In Kyrgyzstan and Tajikistan, vocational education (VE) is divided into three levels: initial, secondary, and higher. The initial $V E$ ensures obtaining a working profession (of the primary qualification) and is implemented in the educational institutions, called vocational schools; the secondary VE in the colleges; and higher $V E$ in the educational institutions having the status of a university (university, institute, academy).

In order to integrate the system of vocational education into the world educational space, the Kyrgyz Republic and Republic of Tajikistan have switched to a multilevel training system. These universities have already trained Bachelors according to this multilevel educational system, and in the upcoming 2016/2017 academic year, they will move to the second level of training - training of Masters of Vocational Education.

According to the State Educational Standard of Higher Vocational Education (SES HVE), Masters of Vocational Education should be ready to implement the following tasks:

\footnotetext{
G. Hakimov ( $ه)$

Vice-Rector for Science and Implementation, Technological University of Tajikistan, Dushanbe, Tajikistan

e-mail: gafurjon-68@mail.ru

K. Dykanaliev

Department of Engineering Pedagogy, Kyrgyz State Technical University named after

I. Razzakov, Bishkek, Kyrgyzstan

e-mail: kalybek_1963@mail.ru
} 
1. Educational and professional

2. Scientific and research

3. Pedagogical designing

4. Organization and management

5. Production and technological

To accomplish the above tasks, a Master of Vocational Education must have certain competences in the educational standard: universal and professional.

\subsection{The Competencies of Masters of Vocational Education}

In the context of globalization, a major factor for the successful functioning and training of competitive specialists that meet the requirements of the labour market is the integration into a single educational space.

The colleagues from Central Asian countries, namely, Tajikistan, Kyrgyzstan, and Kazakhstan, have initiated and implemented several educational projects within the framework of the international GIZ project and the regional program "Vocational education in Central Asia", the component "Vocational education - training of teachers of the secondary vocational education" of the SUCCESS program (Education and Teacher Network in the PBBZ framework).

According to Alekhina O. F., Gontar V. V., and Lavrenteva V. A. "a qualitative development of the intellectual potential is characterized by the increase of the personal qualifications of each employee's capabilities in the field of research and development work to make the highest quality decisions within his/her competence" (Alekhina et al. 2004, p. 44).

It should be noted that the qualification characteristics and competences of Masters are reflected in the Regulation "On Master's degree programmes", approved by the Municipality of the Republic of Tajikistan as Regulations on baccalaureate, specialist, and Master's degree (Municipality of the Republic of Tajikistan 2007).

\subsection{The Competences of Masters, Formed as a Result of Implementation of the Scientific Researches}

As a result of the implementation of a scientific research, a graduate student must acquire the following professional competences:

- Present the results of the research, compare, and critically evaluate the generalized results obtained by the domestic and foreign researchers; identify and formulate relevant scientific problems in the selected theme of the industry.

- Justify the timeliness, theoretical, and practical significance of the chosen research topic. 
- Conduct independent research in accordance with the program developed.

- Present the results of the study in the form of the thesis, articles, patents for inventions, adoption deed, speaker's paper, or research report.

- Under the direct supervision of the leading scientist in the field, develop training guidelines and work programs of the training courses.

Based on the goals and objectives of the research project, a graduate student must know:

- Specifics of the scientific researches in the chosen field

- General scientific and special methods of researches in the field of the Master's program

- Principles of arranging of the scientific research activities

- Content of the research tools

- Technology of the scientific research activities

- Be able to:

Formulate the scientific range of problems in the selected field.

Justify the urgency of the chosen research area.

Choose the means and methods for solving the problems set in the scientific research.

Use the methods of the scientific research.

Justify the conclusion of the research results.

Have peer review and review of the scientific publications.

- Possess:

Methods for conducting research in the chosen field

Methods of analysis and self-assessment and critical approach, contributing to the development of the individual researcher

Techniques for processing of the empirical data obtained and their interpretation.

\subsection{The Structure and Content of the Scientific Research of a Graduate Student}

As a result of the research work, a student should get practical skills on how to conduct research activities and to process the findings. The specific practical skills and abilities are defined in the Principal Education Program (PEP) of the higher vocational education. The total number of credits of the PEP for training of Masters makes 120 credits $(100 \%)$. Thirty credits are allocated for the research-oriented subjects and the research practicum - this is the fourth part of the total number of credits, i.e. $25 \%$.

The level of readiness of Bachelors to the scientific research (SR) is shown in the below diagram (cp. Fig. 19.1). Under the readiness for the scientific research, we 


\section{The level of preparedness to carry out scientific researches}

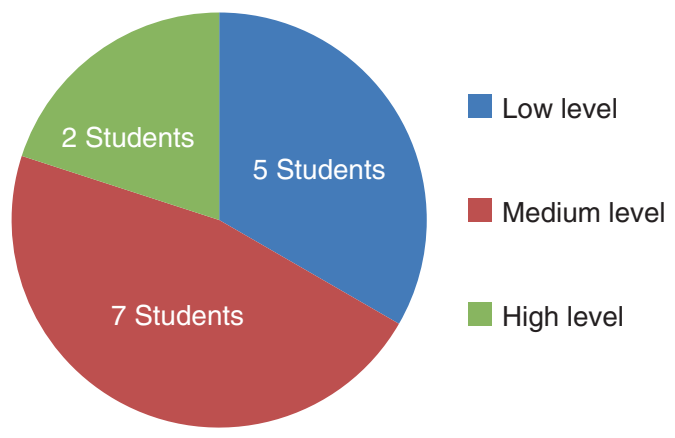

Fig. 19.1 Research activities

understand the successful defence of the graduation thesis (GT). The diagram is made according to the results of defence of the final qualifying papers of Bachelors of Vocational Education. The diagram shows that only a third of graduates are ready to carry out.

Total number of persons completed the training - 14 students (100\%), of which:

- Five Bachelor's degree students defended their graduate thesis (GT) and received the grade of "Excellent", which makes 36\%.

- Seven Bachelor's degree students defended their graduate thesis (GT) and received the grade of "Good" $-50 \%$.

- Two Bachelor's degree students defended their graduate thesis (GT) and received the grade of "Satisfactory" $-14 \%$.

It should be noted that the scientific-specific subjects and other types of research activities of students in the training programs of Bachelors of Vocational Education make up only $10 \%$ of the total number of credits, i.e. 24 credits of the total 240.

Based on the above indicated and on the recommendations of the GIZ program's experts, the total number of credits of the subjects that form the scientific research competence of Masters, increased up to $25 \%$.

In the course of the scientific research activities, the students in the Master's programs use the technology of classical (traditional), student-centred learning, information technology, technology of project, and problem-based learning, adopted in the educational process.

The students in the Master's programs can apply the scientific methods, which include observation, comparison, counting, measurement, experiment, generalization, abstraction, formalization, analysis, and synthesis, induction and deduction, analogy, modelling, idealization, ranking, axiomatic, hypothetical, historical, and system methods (Rahimov 2007, p. 12). 


\subsection{Provision with the Training and Methodological Package for Conducting Scientific Researchesand Self- Preparation of Master's Thesis}

The graduate students must be provided with the following:

- Access to the databases and library stocks in accordance to the full list of subjects (modules) of PEP

- The possibility for the rapid exchange of information with foreign universities, companies, and organizations

As part of the research activity, a Master student shall:

- Plan scientific research activities, including familiarization with the subject of the research in this field of activity, and define methodologies and methods of the research.

- Conduct research.

- Draw up the research report, which includes scientific publications on the topic of research, abstracts about the results of the work, research reports, adoption deed, and patents for inventions.

- Make self-assessment of the activities performed during the period of research.

\subsection{Forms of Midpoint and Final Assessment Following the Results of the Scientific Researches}

The form of the midpoint and final assessment of the scientific researches of the graduate students is an attestation of the results for the whole period of implementation of the research work in the Department (where a student studies) to be held by a special commission with the participation of a research supervisor of Master's thesis.

First, a graduate student defends his/her Master's thesis in front of the Department Commission. After getting the conclusion of the Department, he/she is allowed to defend the thesis at the meeting of the State Attestation Commission.

Assessment criteria:

- The level of performing experimental and research programs, the degree of independence, quality of the data processing, and their interpretation considering the development of the research activities of the graduate student.

- The degree of psychological readiness of the graduate student to work in the modern conditions, his/her understanding of the goals and challenges of the modern specialist in the chosen field of industry.

- The level of development of didactic skills, methodological, and technical training to conduct scientific research in modern conditions. 
- Assessment of the ability to plan and to predict the results of his/her activities, to consider the real possibilities and reserves.

- Assessment of the activity of work of the graduate student to improve his/her professional level, the search for effective methods and technologies in conducting researches.

- The degree of development of personal qualities of the graduate student (the culture of communication, the level of intellectual, and moral development and others).

- After each year of education in the Master's degree program and based on the results of the research performed, the graduate student submits for publication the following: theses, articles, reports, or scientific report, as well as prepares presentations for the scientific and scientific-practical seminars, conferences, and forums in order to develop his/her rhetorical abilities.

\subsection{Conclusions and Further Perspectives of the Researches}

Currently, three persons are enrolled in the Master's program of KSTU named after I. Razzakov. The university tests the program for training of Masters of Vocational Education, elaborated jointly with the experts of the GIZ project, which is totally new to Tajikistan and Kyrgyzstan.

The PEP Regulation allows introducing changes in the program for up to $15 \%$ of the total list of subjects.

\section{References}

Alekhina, O. F., Gontar, V. V., \& Lavrentiev, B. A. (2004). Formirovanie kadrov upravlenia na promyshkennyh predpriatiah. Novgorod: Voljskaia gosudarstvennaia injenerno-pedagogicheskaia akademia.

Kojuhar, V. M. (2010). Osnovy nauchnyh issledovanyi: uchebnoe posobie. Moskva: Izdatelsko-torgovaia korporacia "Dashkov i K". Retrieved from http://sa.technolog.edu.ru/ files\%5Cchumakov\%5CUchebnik\%20po\%20ONI\%20(Kozhuhar\%20V.M.).pdf

Kuzin, F. A. (2001). Metodika napisania. Pravila oformlenia. Poriadok zashity:prakticheskoe posobie dlia doktorantov, aspirantov I magistrov. Moskva: Os-89.

Leonov, V. P. (1986). Refeririovanie I annotirovanie nauchno-technicheskoi literatury. Volgograd: Izdatelstvo VolGU. Retrieved from http://www.ozon.ru/context/detail/id/32813513/

Milner, B. Z. (2003). Upravlenie znaniami. Moskva: INFRA-M.

Municipality of the Republic of Tajikistan. (2007). Polojenie o bakalavriate, specialiste i magistrature, Pravitelstvo Respubliki Tajikistan 30. December 2007.

Popkovskaia, P. I. (2002). Metodologia nauchnyh issledovanyi: kurs lekcyi. Minsk: OOO Informpress.

Popov, V., Blank, I., \& Ivanickyi, V. (2002). Osnovy nauchnyh issledovanyi. Kiev: Vyshaia shkola. Puzynia, K. F., \& Kazancev, A. K. (1999). Organizacia i planirovania NIR OKR. Moskva: Vyshaia shkola. 
Rahimov, A. Z. (2007). Organizacia uchebnoi i nauchno-issledovatelskoi raboty srudentov. Ufa: Bashkirskyi gosudarstvennyi universitet.

Ruzavin, G. I. (2001). Metodologia nauchnyh issledovanyi. Moskva: UNITI.

Teilor, F. U. (1991). Principy nauchnogo managmenta. Moskva: Izdatelstvo Progress. Retrieved from http://urss.ru/cgi-bin/db.pl?lang=Ru\&blang=ru\&page=Book\&id=16606

Usachev, I. V., \& Iliasov, I. I. (1980). Metodika poiska nauchnoi literatury, chtenia i sostavlenia obzora po teme issledovania: Provedenie informacionnogo etapa nauchno-issledovatelskoi raboty. Moskva: Izdatelstvo Moskovskogo universiteta. Retrieved from http://lib.mgppu.ru/ OpacUnicode/index.php?url=/notices/index/IdNotice: 169631/Source:default

Vertakova, U. V., \& Simonenko, E. S. (2008). Upravlenie innovaciami: Teoria i praktika. Moskva: Eksmo. Retrieved from http://www.alleng.ru/d/manag/man207.htm

Open Access This chapter is licensed under the terms of the Creative Commons Attribution 4.0 International License (http://creativecommons.org/licenses/by/4.0/), which permits use, sharing, adaptation, distribution and reproduction in any medium or format, as long as you give appropriate credit to the original author(s) and the source, provide a link to the Creative Commons license and indicate if changes were made.

The images or other third party material in this chapter are included in the chapter's Creative Commons license, unless indicated otherwise in a credit line to the material. If material is not included in the book's Creative Commons license and your intended use is not permitted by statutory regulation or exceeds the permitted use, you will need to obtain permission directly from the copyright holder.

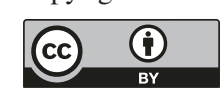

